\title{
CHARACTERIZATION OF UNTREATED AND COMPOSTED BIOCHAR DERIVED FROM ORANGE AND PINEAPPLE PEELS
}

\author{
Caracterización de biocarbón sin tratar y compostado derivado de cáscaras de naranja y piña \\ Elizabeth CHÁVEZ-GARCÍA ${ }^{1,2 *}$, Javier AGUILLÓN-MARTÍNEZ ${ }^{3}$, \\ Arturo SÁNCHEZ-GONZÁLEZ ${ }^{2}$ and Christina SIEBE ${ }^{2}$
}

\author{
${ }^{1}$ Posgrado en Ciencias Biológicas, Universidad Nacional Autónoma de México, Ciudad Universitaria, CP \\ 04510, Mexico City, Mexico \\ ${ }^{2}$ Instituto de Geología, Universidad Nacional Autónoma de México, Ciudad Universitaria, CP 04510, Mexico \\ City, Mexico \\ ${ }^{3}$ Instituto de Ingeniería, Universidad Nacional Autónoma de México, Ciudad Universitaria, CP 04510, Mexico \\ City, Mexico \\ *Corresponding author: eliza@ciencias.unam.mx
}

(Received: March 2019; accepted: September 2019)

Key words: pyrolysis, soil amendment, fruit waste, composting, organic pollutants

\begin{abstract}
Biochar production is a waste management option for agro-businesses and it is widely used to sequester carbon and to improve soil fertility. The preferred feedstock to produce biochar has been lignin and cellulose rich materials, or a mixture of industrial or animal residues. However, residues rich in soluble sugars, pectin and polysaccharides, such as fruit wastes, have been rarely used and are widely available. Furthermore, the release of toxic compounds has been reported when untreated biochars are used as soil amendments. Here we test if composting is able to eliminate toxicants and to improve biochar characteristics. We produced biochar out of orange and pineapple peels by pyrolysis, and characterized the physical and chemical properties of untreated and composted biochars. The analyses show that the untreated biochar has a high soluble salt and $\mathrm{C}$ content, an alkaline nature and high porosity. The composting process increased the $\mathrm{pH}$, micronutrients, exchangeable cations, oxygen-based functional groups and the labile carbon, and reduced the PAHs and dioxins. Our results reveal that orange and pineapple peels are suitable raw materials for producing biochar but should be composted before using them as soil amendments.
\end{abstract}

Palabras clave: pirólisis, abono, desperdicios de fruta, compostaje, contaminantes orgánicos

\section{RESUMEN}

La producción de biocarbón es una opción para el manejo de residuos agroindustriales, el cual se usa ampliamente para secuestrar carbono y mejorar la fertilidad del suelo. Para producirlo, generalmente se han utilizado materiales ricos en lignina y celulosa o una mezcla de residuos industriales o animales. Sin embargo, los residuos ricos en azúcares solubles, pectina y polisacáridos, como los desechos de frutas, se han utilizado poco y están ampliamente disponibles. Además, se pueden liberar compuestos tóxicos 
cuando se utilizan biocarbones no tratados como abonos. En este trabajo probamos si el compostaje es capaz de eliminar toxinas y de mejorar las propiedades de biocarbones producidos a partir de la pirólisis de cáscaras de naranja y piña. Caracterizamos las propiedades físicas y químicas de lotes de biocarbón no tratado y compostado. Los análisis muestran que el biocarbón no tratado tiene un alto contenido de sales solubles y $\mathrm{C}$, naturaleza alcalina y alta porosidad. El proceso de compostaje aumentó el $\mathrm{pH}$, los micronutrientes, los cationes intercambiables, los grupos funcionales y el carbón lábil, a la vez que redujo los HAP y las dioxinas. Nuestros resultados muestran que las cáscaras de naranja y piña son materias primas adecuadas para la producción de biocarbón, pero deben compostarse antes de ser usados como abonos.

\section{INTRODUCTION}

Each year, a great quantity of biomass waste is generated from agricultural, industrial and urban activities worldwide (Abdelhafez et al. 2014, Prakongkep et al. 2015, Lam et al. 2016). However, its disposal by composting, landfilling and open burning is not thoroughly practical since these residues can attract harmful fauna and release unpleasant odors, greenhouse gas (GHG) or toxic compounds that might contaminate surface water bodies and soil (Lam et al. 2016, Nanda et al. 2016). For instance, in Mexico City about 6200 t of organic domestic waste were generated daily during 2017 (SEDEMA 2017). For its recollection and disposal, municipalities implemented more than 8300 sweepers, 2500 waste collectors vehicles, 4700 operators and more than 3500 workers not formally employed (SEDEMA 2017). Traditionally, the organic waste from Mexico City has been composted to reduce its volume and to produce organic fertilizers (Michler 2013, TTEI 2013). However, compost is readily degraded by soil microorganisms and can negatively affect the air quality due to the release of $\mathrm{CO}_{2}$ or toxicants such as $\mathrm{NH}_{3}$ (Bass et al. 2016, Chávez-García and Siebe 2019). This hinders the effectiveness of composting as the main waste management option in large cities. Thus, the application of a proper management plan for the recycling or confinement of organic waste is necessary to reduce pollution, public health problems and disposal costs.

Additionally, it is important to emphasize that these residues can have a high economic value. For instance, many of them can be used for gasification schemes or biomass pyrolysis, reducing the volume and toxicity of organic waste (Lam et al. 2016, Nanda et al. 2016).

The conversion of biomass through pyrolysis is ecologically and economically appealing since energy (e.g., biogas) can be produced simultaneously with biochar (Cha et al. 2016, Tripathi et al. 2016). Several countries, particularly in the European Union, are promoting the use of organic biomass to generate energy as an alternative for the combustion of fossil fuels (Lam et al. 2016, Tag et al. 2016, Zema et al. 2018). The impact of this practice has a high potential to effectively diminish the $\mathrm{CO}_{2}$ fluxes into the atmosphere if the produced biochar is used as soil amendment (Lehmann 2007, Cha et al. 2016).

Biochar is a carbon-rich solid produced from the thermal decomposition of biological wastes in absence of oxygen and with relatively low temperatures $\left(150-300{ }^{\circ} \mathrm{C}\right)$ (IBI 2015, Tripathi et al. 2016, EBC 2017). Its large specific surface and porosity makes biochar a potent adsorbent of organic compounds and heavy metals (Chen et al. 2011, Cha et al. 2016). Many biochars also act as soil fertilizers and $\mathrm{pH}$ buffers creating a more favorable habitat for plants and microbial organisms (Brewer 2012). In addition, the recalcitrant nature of biochar contributes to $\mathrm{C}$ sequestration in soils, reducing GHG emissions (Brewer 2012). However, certain negative effects have been reported such as nutrients immobilization, $\mathrm{CH}_{4}$ and $\mathrm{N}_{2} \mathrm{O}$ emissions, low soil water storage, or the introduction of polycyclic aromatic hydrocarbons (PAHs) and other toxicants when untreated biochars are used (DeLuca et al. 2009, Borchard et al. 2014, IBI 2015, Liu et al. 2017).

Biochars can be treated to raise their soil-improving effects. A low-price, fast and ecofriendly way to improve them is by a composting process (Wiedner et al. 2015). Composting might eliminate biochar toxic compounds such as benzene, naphthalene or furan (Borchard et al. 2014). Additionally, it can hasten the formation of oxygen-containing functional groups on the biochar surface, which may increase its reactivity with the soil mineral phase (Wiedner et al. 2015).

The physical and chemical properties of biochars, either untreated or composted, improve the available water holding capacity, the aeration and the nutrient 
availability in soils (Brewer 2012, Liu et al. 2017) by increasing medium and coarse pores, diminishing soil bulk density and increasing the ion-exchange capacity of the soil (Downie et al. 2009, Brewer 2012). The properties of biochars depend not only on the original biomass but also on the thermal conditions by which they are made (Cha et al. 2016, Tag et al. 2016, Sun et al. 2017). The structure and nutrient composition of most feedstock is imprinted on the biochar, while the temperature controls the abundance of the thermaldegradation products (Dai et al. 2013, Tag et al. 2016). Thus, in the strictest sense, each biochar made with a particular biomass and production process presents unique features, which need to be considered when it is used to ameliorate a particular soil.

Most biochars have been produced from wood and agricultural residues, whose major components are lignin, cellulose and hemicellulose, or from industrial or animal waste, mainly composed of inorganic elements, lipids, proteins, etc. (Cha et al. 2016, Tripathi et al. 2016, Gondek et al. 2017). Fruits are another type of biomass widely produced by juice and other fruit processing factories in the world, which generates a significant amount of residues every year (FAO 2014, 2015), being the peels a renewable resource to be exploited (Lam et al. 2016, Nanda et al. 2016). Fruit peels have considerable amounts of fixed C (30-36 wt \%), soluble sugars, pectin, cellulose, hemicellulose, lignin and lipids, which makes them a potential feedstock for pyrolysis conversion into useful products (Lam et al. 2016, Romelle et al. 2016).

Oranges and pineapples (OPP) represent some of the most produced fruits in the world, being Brazil, USA, China, India, Costa Rica and Mexico among the largest fruit producers (Rohrbach et al. 2003, FAO 2014, 2015, Romelle et al. 2016, Zema et al. 2018). Within the international industry, Mexico holds the fifth place in orange production and the seventh in pineapple yield (Rohrbach et al. 2003, FAO 2015). Peels of these fruits could be suitable raw material for multiple biochar applications (Abdelhafez et al. 2014, Aon et al. 2015, Lam et al., 2016, Nanda et al. 2016). However, most biochars from orange peels have usually been used as sorbents of ions such as $\mathrm{Cu}$ (II) (Pellera et al. 2012), $\mathrm{Pb}$ (II) (Abdelhafez et al. 2014) and Cd (Tran et al. 2016), as well as of organic compounds such as naphthalene (Chen and Chen 2009, Chen et al. 2011) or pharmaceuticals (Fernandez et al., 2015) for water treatment, with only one study of pineapple peels biochar to adsorb Cr(VI) (Wang et al., 2016). Although OPP biochars can increase germination, total $\mathrm{C}$, cation exchange capacity (CEC), nutrient availability and $\mathrm{pH}$ in soils
(Oh et al. 2012, Dai et al. 2013, 2014), few attempts have been made to produce fertilizers.

The exploration of different feedstock opens new possibilities for the development of efficient amendments to solve specific soil problems related to $\mathrm{pH}$ imbalances in acid or alkaline soils, water retention in arid areas or nutrient supply in land-managed soils. Besides, a significant amount of OPP peels are generated from the processing industries and the juice and fruit street-selling in Mexico (Gómez and Schwentesius 1997, CEFP 2002, FAO 2015). These by-products have been used as substrates for the extraction of enzymes, alcohols or organic acids (Ketnawa et al. 2012, Lam et al. 2016, Zema et al. 2018). However, peels are still not fully used and large amounts of peel cellulose are discarded (ca. $30-50 \%$ in weight) (Ketnawa et al. 2012, Lam et al. 2016, Romelle et al. 2016, Zema et al. 2018), while they could help to improve soil fertility.

The aim of this study was to evaluate if composting is able to eliminate toxicants and to improve the characteristics of biochar produced out of OPP peels in order to assess their potential use as soil amendments. Mixing compost with biochar further produces a soil amendment with a labile and a recalcitrant carbon component, promoting both, microbial activity and soil carbon sequestration. This study contributes to the overall biochar production and post-treatment scheme of biochar and to the recycling of fruit waste for soil fertility improvement and $\mathrm{C}$ sequestration enhancement.

\section{MATERIALS AND METHODS}

\section{Feedstock}

OPP peels were gathered from local markets in Mexico City. This feedstock was chosen due to its large availability, greater dry biomass than leafy vegetables, and ease of drying without signs of putrefaction. Prior to pyrolysis, OPP peels were dried outdoors for about 2 weeks during the dry season (March-May, 2015) to ensure maximum moisture of $45 \%$ in the material. The feedstock did not receive any other pretreatment before pyrolysis. An aliquot of the feedstock was analyzed for its total $\mathrm{C}$, organic $\mathrm{C}$ and total $\mathrm{N}$ contents: $42 \pm 1.1,40 \pm 0.4$ and $0.6 \pm$ $0.03 \%$ for orange peels, and $44 \pm 0.4,39 \pm 1.1$ and $0.8 \pm 0.01 \%$ for pineapple peels, respectively.

\section{Pyrolysis facility}

The biochar was produced using a lab-scale fast pyrolysis reactor at the Gasification Laboratory of the 
Institute of Engineering of the National Autonomous University of Mexico (UNAM). The setup comprised a stainless steel tube (inner diameter: $81 \mathrm{~mm}$, outer diameter: $89 \mathrm{~mm}$ and height: $114 \mathrm{~mm}$ ) covered with a fitting lid to restrict the access of air. This allowed the material to be charred rather than combusted.

For the biochar production, the internal reactor chamber was externally heated by gas until its walls reached ca. $200^{\circ} \mathrm{C}$ and then, $2 \mathrm{~kg}$ of OPP peels mixed in a 1:1 proportion (not chopped) were loaded into the reactor. An electric resistance $(3 \mathrm{~kW}, 220 \mathrm{~V})$ was used to maintain and raise the heat of the chamber atmosphere until it reached its highest treatment temperature (HTT) $200-250{ }^{\circ} \mathrm{C}$. The HTT was monitored by a thermocouple and kept for ca. 80 - 90 $\min$ (residence time) and the reactor was opened after a total time of $110 \mathrm{~min}$. We repeated this process 74 times to obtain $50 \mathrm{~kg}$ of biochar. The biochar samples were allowed to cool to ambient temperature, ground, sieved $(5 \mathrm{~mm})$ and mixed.

\section{Composted biochar preparation}

Twenty-six kilograms of biochar were mixed with $35 \mathrm{~kg}$ of immature compost (ca. 40 days) from pruning conifers (not sieved). The mix ratio of dry mass was $1: 1$. The biomass was placed in a plastic container outdoors and deionized water was used to maintain moist conditions. The biomass humidity $(50 \%)$ and the daily turning favored a rapid composting process that lasted 40 days. During this period the composted biochar reached the maximum temperature of $38^{\circ} \mathrm{C}$ and subsequently decreased to a constant value $\left(22^{\circ} \mathrm{C}\right)$. We expected the compost would reach values above $60^{\circ} \mathrm{C}$. However, the mass-volume relationship and the high number of aeration holes of the plastic container likely hyperventilated the compost, not allowing the increase in temperature (Petiot and de Guardia 2004, Epstein 2011).

\section{Biochar characterization}

Three composite samples of $500 \mathrm{~g}$ of untreated and composted biochar (sieved at $2 \mathrm{~mm}$ ) were used and the analyses were performed in duplicate. The yield was calculated using the following formula:

Yield $(\%)=[\mathrm{Wb} / \mathrm{Wf}] \times 100$,

where $\mathrm{Wb}$ is the biochar mass $(\mathrm{g})$ and $\mathrm{Wf}$ is the dry mass of the feedstock $(\mathrm{g})$. The moisture content of the biochar samples was determined gravimetrically. Particle density (PD) and total pore volume (TPV) were measured by helium displacement using a gas pycnometer (AccuPyc II 1340 Pycnometer). The bulk density (BD) was calculated as the weight of dry biochar per unit volume after 10 times compression in a test tube (EBC 2017).

The percentage of water holding capacity (WHC) was measured by soaking the biochar in a $0.005 \mathrm{M}$ $\mathrm{CaSO}_{4}$ solution for $24 \mathrm{~h}$ (EBC 2017). Afterwards, the samples were placed on dry sand for $2 \mathrm{~h}$. The saturated samples were weighed (Ws), dried $\left(40{ }^{\circ} \mathrm{C}\right)$ until no further water loss and reweighed to record the oven-dried sample (Wd). The WHC was calculated as follows:

\section{$\mathrm{WHC}=[\mathrm{Ws} / \mathrm{Wd}-1] \times 100$}

The $\mathrm{C}, \mathrm{N}$ and $\mathrm{H}$ analyses were performed with an elemental analyzer CNHS/O Perkin Elmer 2400 series II equipped with a thermic conductivity detector and using helium as carrier gas, and setting combustion temperature at $975{ }^{\circ} \mathrm{C}$ and reduction temperature at $640{ }^{\circ} \mathrm{C}$. Oxygen was analyzed at $1060^{\circ} \mathrm{C}$ using a Flash 2000 analyzer. The results were used to calculate the elemental ratio $\mathrm{C} / \mathrm{N}$ and molar ratios $\mathrm{H} / \mathrm{C}$ and $\mathrm{O} / \mathrm{C}$.

The $\mathrm{pH}$ and electric conductivity (EC) were measured using a 1:20 dilution in deionized water after stirring for $18 \mathrm{~h}$ (IBI 2015). The determination of extractable metals ( $\mathrm{Fe}, \mathrm{Cu}, \mathrm{Zn}$ and $\mathrm{Mn}$ ) was done by diethylenetriaminepentaacetic acid (DTPA) extraction (Lindsay and Norvell 1978) and quantification of $\mathrm{Fe}, \mathrm{Cu}, \mathrm{Zn}$ and $\mathrm{Mn}$ by atomic absorption spectroscopy (Perkin Elmer PinAAcle 900H). The extractable phosphorous content of biochar was analyzed by the Olsen method (van Reeuwijk 1992) and the exchangeable cations $(\mathrm{Ca}, \mathrm{Mg}, \mathrm{Na}$ and $\mathrm{K}$ ) were extracted with ammonium acetate and quantified using atomic absorption spectroscopy (Ca and $\mathrm{Mg}$ ) or flame atomic absorption spectroscopy ( $\mathrm{K}$ and $\mathrm{Na}$ ) (Bower et al. 1952, van Reeuwijk 1992).

We used Fourier-transform infrared spectroscopy (FT-IR) to estimate the concentration of the carboxylic and carboxylates groups $\mathrm{COOH} / \mathrm{COO}^{-}$(Celi et al. 1997), the hydrophobicity (Capriel et al. 1995) and the percentage of aromaticity (Wiedemeier et al. 2015). Biochar aliquots (5 mg C) were mixed with $\mathrm{KBr}(200 \mathrm{mg})$ and pressed to tablets. Two spectra within the range of 400 to $4000 \mathrm{~cm}^{-1}$, with a resolution factor of $4 \mathrm{~cm}^{-1}$ and $50 \mathrm{scans}$, were obtained from each tablet.

To evaluate the possible toxicity of the biochars, we performed a germination test with commercial lettuce seeds (Lactuca sativa L.) (IBI 2015). We added 0 (control) or $5 \mathrm{~g}$ (ca. $7.9 \mathrm{t} / \mathrm{ha}$ ) of untreated or composted biochar to a cotton bed in petri dishes. In 
each one, 10 ethanol-sterilized seeds were placed and every treatment was replicated three times. All petri dishes were kept closed and under greenhouse conditions for 11 days, with the following mean conditions: $18{ }^{\circ} \mathrm{C}, 49 \%$ of relative humidity and $11 \mathrm{~W} / \mathrm{m}^{2}$ of solar radiation. Irrigation was done with deionized water as necessary to maintain moist conditions.

Finally, toxicants derived from the thermochemical conversion process to make the biochars were also assessed. The analysis of polychlorinated dibenzop-dioxins and dibenzofurans (PCDD/PCDF) was done by standardized methods in a commercial lab (ÖKOMETRIC GmbH, Germany) according to the procedure DIN CEN/TS 16190 (DIN SPEC 91267) 2012-05. Total PAHs concentrations (EPA's 16 priority pollutants) of the biochars were analyzed in agreement with the requirements of the European Biochar Certificate (EBC 2017) by Eurofins Umwelt Ost GmbH (Bobritzsch-Hilbersdorf, Germany), according to DIN EN ISO/IEC 17025:2005 D-PL14081-01-00.

\section{Data analysis}

Properties of the untreated and the composted biochars were analyzed for significant differences using Mann-Whitney-Wilcoxon tests, except for the FT-IR spectra, PAHs and PCDD/PCDF concentrations. Germination results were evaluated for significant differences using a Kruskal Wallis test and a Conover post-hoc test for pairwise comparisons (PMCMR package; Pohlert 2014). Analyses were performed using the software $\mathrm{R}$ version 3.5.0 (RDCT 2018).

\section{RESULTS AND DISCUSSION}

The yield obtained for the untreated biochar was of $40 \%$ (Table I). The pineapple peels carbonized faster and more evenly than the orange peels, probably because the former contain less crude proteins, lipids and ash (Romelle et al. 2016). Despite this difference in carbonization, pineapple peels have been scarcely used to produce biochar compared to citrus peels (Table I).

The most common HTT reported in previous studies has been $300-350{ }^{\circ} \mathrm{C}$, and the preferred residence time to produce biochar is $120 \mathrm{~min}$ (Table I). The HTT is one of the most important parameters during pyrolysis that influence the properties of biochar because the fundamental changes (e.g., the release of volatiles) are all temperature dependent (Downie et al. 2009). For example, as temperature increases, the specific surface area of biochar increases, particles can also become smaller and the organic matter is more recalcitrant (Liang et al. 2016). High HTT during pyrolysis can reduce the available plant nutrients and the CEC due to functional groups release (Liang et al. 2016, Tag et al. 2016). However, temperature intervals under which these changes occur vary with feedstock (Downie et al. 2009).

Our analysis showed that biochar yield was similar to the one obtained from oranges by Chen et al. (2011), Pellera et al. (2012) and Fernandez et al. (2015), but higher than the results achieved by other studies (Dai et al. 2013, 2014, Abdelhafez et al. 2014, Stella Mary et al. 2016, Tran et al. 2016, Wang et al. 2016; Table I). These differences could be related to the HTT and the residence time, since biochar yield decreases if the pyrolysis temperature is increased (Cha et al. 2016, Stella Mary et al. 2016, Tran et al. 2016). In our case, a HTT of $200-250{ }^{\circ} \mathrm{C}$ could explain the higher yield obtained, in comparison to the studies mentioned whose HTT employed was > $350{ }^{\circ} \mathrm{C}$ (Abdelhafez et al. 2014, Stella Mary et al. 2016, Tran et al. 2016, Wang et al. 2016).

Moisture is not a commonly measured parameter; however, it can indicate the adsorptive capacity of biochars, because pores that could be available for organic molecules are filled with water (Santos et al. 2015). Since our untreated biochar had higher moisture content compared to those of Aon et al. (2015) and Tran et al. (2016) whose HTT was < $300{ }^{\circ} \mathrm{C}$ (Table I), we assume that evaporation of the feedstock moisture could not be completed at the HTT we used. In the case of the composted biochar, moisture content was very high $(>50 \%)$ due to the added water during the composting process and possibly due to the conifer pruning added.

The PD of the untreated and composted biochar was 1.53 and $1.74 \mathrm{~g} / \mathrm{cm}^{3}\left(\mathrm{p}=1.08^{-5}\right)$, respectively (Table I). Other studies have reported values from 0.58 (at $200{ }^{\circ} \mathrm{C}$ ) to $2.36 \mathrm{~g} / \mathrm{cm}^{3}$ (at $800{ }^{\circ} \mathrm{C}$ ) in biochars from pine pellet and manure (Tsai et al. 2012, Santos et al. 2015). In general, biochar PD values typically range from 1.5 to $1.8 \mathrm{~g} / \mathrm{cm}^{3}$ (Jankowska et al. 1991 in Downie et al. 2009, Liang et al. 2016). However, high temperatures $\left(>800^{\circ} \mathrm{C}\right)$ or rich-ash feedstock can increase the PD values due to loss of volatile compounds, concentration of ash and gain in structural organization (Downie et al. 2009, Tsai et al. 2012, Santos et al. 2015).

The BD of the untreated and composted biochar was 0.36 and $0.39 \mathrm{~g} / \mathrm{cm}^{3}$ (no significant differences: $\mathrm{p}=0.1)$, respectively. Other authors report values 
TABLE I. PHYSICAL CHARACTERIZATION OF THE UNTREATED AND COMPOSTED BIOCHARS FROM THIS STUDY AND PREVIOUS WORKS (UNTREATED BIOCHARS ONLY). OPP = ORANGE AND PINEAPPLE.

\begin{tabular}{|c|c|c|c|c|}
\hline $\begin{array}{l}\text { Variable } \\
\text { (Unit) }\end{array}$ & $\begin{array}{l}\text { Untreated biochar } \\
\text { Mean } \pm \text { SE }\end{array}$ & $\begin{array}{l}\text { Composted-biochar } \\
\text { Mean } \pm \text { SD }\end{array}$ & $\begin{array}{l}\text { Previous } \\
\text { studies }\end{array}$ & Reference \\
\hline Feedstock & OPP peels & $\begin{array}{l}\text { OPP peels biochar } \\
\text { and conifers pruning }\end{array}$ & $\begin{array}{c}\text { Orange peels } \\
\text { Citrus peels } \\
\text { Pineapple peels }\end{array}$ & $\begin{array}{c}1-5,8,10,12,13 \\
7,9,11 \\
6,7,14\end{array}$ \\
\hline $\mathrm{HTT}\left({ }^{\circ} \mathrm{C}\right)$ & $200-250$ & & $\begin{array}{c}<250 \\
300-350 \\
400-500 \\
600-700 \\
700-800\end{array}$ & $\begin{array}{c}1-3,10 \\
3-5,7,9,12,14 \\
2,3,6-8,11,13,14 \\
2-5,13 \\
13,14\end{array}$ \\
\hline Residence time (min) & $80-90$ & & $\begin{array}{c}20-30 \\
60 \\
120 \\
360 \\
960 \\
1200\end{array}$ & $\begin{array}{c}5,9 \\
11,12 \\
4,6,7,13,14 \\
2,3,5,13 \\
1 \\
10\end{array}$ \\
\hline Yield (\%) & 40 & & $\begin{array}{c}5-15 \\
20-30 \\
33-40 \\
48-83\end{array}$ & $\begin{array}{c}6,7 \\
3,8,12,13,14 \\
3,5,7,10,13,14 \\
3\end{array}$ \\
\hline Moisture (\%) & $4.9 \pm 0.4$ & $52.2 \pm 1.3$ & $\begin{array}{l}2.4-2.9 \\
3.2-3.9 \\
6.7-6.9\end{array}$ & $\begin{array}{c}9,13 \\
13 \\
13\end{array}$ \\
\hline $\mathrm{PD}(\mathrm{g} / \mathrm{cm})$ & $1.53 \pm 0.004$ & $1.74 \pm 0.01$ & & \\
\hline $\mathrm{BD}(\mathrm{g} / \mathrm{cm})$ & $0.36 \pm 0.001$ & $0.392 \pm 0.013$ & $\begin{array}{l}0.13 \\
0.46\end{array}$ & $\begin{array}{c}8 \\
12\end{array}$ \\
\hline $\operatorname{TPV}\left(\mathrm{cm}^{3} / \mathrm{g}\right)$ & $0.3445 \pm 0.002$ & $0.4253 \pm 0.003$ & $\begin{array}{c}\leq 0.004 \\
0.005-0.01 \\
0.02-0.15\end{array}$ & $\begin{array}{c}7,8,14 \\
2,7 \\
2,14\end{array}$ \\
\hline WHC (\%) & $176.4 \pm 3.0$ & $175.9 \pm 5.6$ & $\begin{array}{l}132 \\
200\end{array}$ & $\begin{array}{c}12 \\
8\end{array}$ \\
\hline
\end{tabular}

*(1) Titirici et al. 2007; (2) Chen and Chen 2009; (3) Chen et al. 2011; (4) Oh et al. 2012; (5) Pellera et al. 2012; (6) Dai et al. 2013a; (7) Dai et al. 2013b; (8) Abdelhafez et al. 2014; (9) Aon et al. 2015; (10) Fernandez et al. 2015; (11) Prakongkep et al. 2015; (12) Stella Mary et al. 2016; (13) Tran et al. 2016; (14) Wang et al. 2016. HTT= highest treatment temperature, $\mathrm{PD}=$ particle density, $\mathrm{BD}=$ bulk density, $\mathrm{TPV}=$ total pore volume, $\mathrm{WHC}=$ water holding capacity

of 0.13 and $0.46 \mathrm{~g} / \mathrm{cm}^{3}$ for orange peels biochar (Abdelhafez et al. 2014, Stella Mary et al. 2016). Biochar BD is, in general, around $0.2-0.5 \mathrm{~g} / \mathrm{cm}^{3}$ (Brewer 2012). However, there can be variations due to feedstock and production processes (Sun et al. 2017). For instance, manure and sludge biochars can have higher $\mathrm{BD}\left(0.54-0.61 \mathrm{~g} / \mathrm{cm}^{3}\right)$ than those of plant biomass $\left(0.14-0.35 \mathrm{~g} / \mathrm{cm}^{3}\right)$ because of the mineral contribution of the former (Sun et al. 2017), while high temperature $\left(>500{ }^{\circ} \mathrm{C}\right)$ produces low-BD biochars compared to lower temperatures $\left(250-500^{\circ} \mathrm{C}\right)$ because the increased development of pores during pyrolysis (Downie et al. 2009).

The TPV of the untreated and composted biochar was 0.34 and $0.43 \mathrm{~cm}^{3} / \mathrm{g}\left(\mathrm{p}=1.08^{-5}\right)$, respectively. Other authors report values lower than $0.15 \mathrm{~cm}^{3} / \mathrm{g}$ for orange or pineapple peels biochar (Table I). These differences could be attributed to feedstock and pyrolysis temperature that control pore formation (Downie et al. 2009, Brewer 2012, Dai et al. 2013). Generally, the greater the TPV of biochar, the greater the retention of water or pollutants (Dai et al. 2013, 


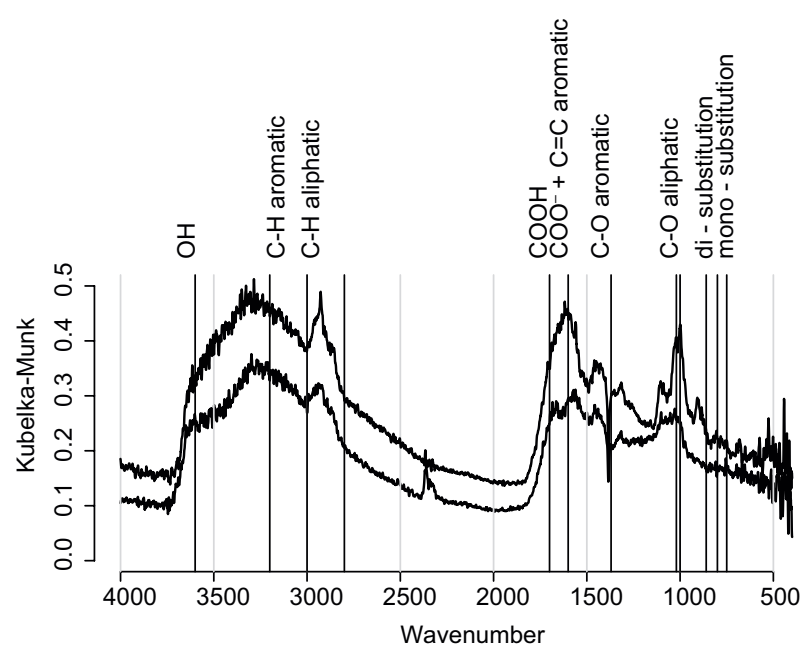

Fig. 1. Fourier transform infrared spectroscopy spectra of the untreated (bottom) and composted (top) biochars

Wang et al. 2016). Thus, it seems convenient to have a low-temperature biochar with high TPV values due to the lower investment to produce it.

The WHC of the untreated and composted biochar was $176 \%$ (no significant differences: $p=1$ ), namely, they can hold almost 2 times their mass of water. Other studies with orange peels biochars mention 132 and $200 \%$ of WHC (Abdelhafez et al. 2014, Stella Mary et al. 2016). The WHC is closely related to the TPV because the porosity determines the available space for water storage (Brewer 2012, Liu et al. 2017). However, biochar hydrophobicity can prevent water from entering the pores (Brewer 2012, Kinney et al. 2012). Fortunately, hydrophobicity is usually decreased by environmental exposure, i.e., by wetting or by composting the biochar (Kinney et al. 2012, Liu et al. 2017).

The $\mathrm{C}$ and $\mathrm{N}$ percentages obtained were 62 and 1.82 for the untreated biochar, and 42 and 1.77 for the composted biochar, respectively $(\mathrm{C}: \mathrm{p}=0.002 ; \mathrm{N}$ : $\mathrm{p}=0.39$; Table II). The decrease in the $\mathrm{C}$ content of the biochar after being composted can be attributed to the lower $\mathrm{C}$ content of the biomass used for the composting process $(19.7 \pm 1.1 \%)$. Our untreated biochar $\mathrm{C}$ content is in line with most previous studies on orange peels biochars (Table II), whose reported values range between 60 and $70 \%$ (Table II).

The $\mathrm{N}$ content in biochars of previous studies ranges between 0.5 and $3.75 \%$ (Table II). The $\mathrm{C} / \mathrm{N}$ ratio of the untreated biochar was 34.1, while values of previous studies showed a variation between 22 and 39 , except for the biochar characterized by Chen et al. (2011) whose $\mathrm{C} / \mathrm{N}$ ratio is 132 (Table II). The $\mathrm{C} / \mathrm{N}$ ratio of the composted biochar decreased significantly to $23.8(\mathrm{p}=0.002)$. An estimated $\mathrm{C} / \mathrm{N}$ ratio of 20 is recommended for soil fertilizers to avoid $\mathrm{N}$ immobilization problems in the soil. In our case, a $\mathrm{C} / \mathrm{N}$ ratio of 34.1 is slightly higher than the recommended one; probably due to the low $\mathrm{N}$ content of OPP peels compared with other fruit shells (Lam et al. 2016, Nanda et al. 2016). However, composting the biochar reduced the $\mathrm{C} / \mathrm{N}$ value, which means that this method could increase the $\mathrm{N}$ content, especially when untreated biochars are mixed with some N-rich material.

The $\mathrm{H}$ and $\mathrm{O}$ percentages obtained were 4.7 and 22.2 , respectively for the untreated biochar and 4.0 and 30.3 for the composted one $(\mathrm{H}: \mathrm{p}=0.002$; $\mathrm{O}$ : $\mathrm{p}=0.002$; Table II). From these data, and from the FTIR spectra (Fig. 1), it is suggested that composting enhanced the formation of oxygen-containing functional groups (Wiedner et al. 2015). The values of the untreated biochar are in line with previous studies, in which the $\mathrm{H}$ and $\mathrm{O}$ percentages range between $1.4-7$ and $4-45 \%$, respectively (Table II). In the case of the $\mathrm{H} / \mathrm{C}$ molar ratio, the untreated biochar had a value of 0.91 , while composting increased significantly the ratio to 1.14 ( $\mathrm{p}=0.002$; Table II). Similar values were found by Chen et al. (2011) and Fernandez et al. (2015) for untreated biochars: 0.92 - 0.94. The $\mathrm{H} / \mathrm{C}$ ratio has been used as a measure of aromaticity, linked to the biochar long-term stability and to its adsorption degree (Chun et al. 2004, Schimmelpfennig and Glaser 2012). For instance, a H/C ratio $\leq 0.6$ can indicate a long-term $\mathrm{C}$ sequestration in soils (Schimmelpfennig and Glaser 2012), while values $>0.6$ suggest the existence of uncharred macromolecules such as carbohydrates or cellulose (Chun et al. 2004). However, the $\mathrm{H} / \mathrm{C}$ ratio depends on several factors like feedstock or production method (Schimmelpfennig and Glaser 2012).

Regarding the $\mathrm{O} / \mathrm{C}$ molar ratio, the untreated and the composted biochars had values of 0.27 and 0.54 , respectively $(p=0.002)$. The former value is in line with Chen and Chen (2009) ratio: $0.24-0.30$. The $\mathrm{O} / \mathrm{C}$ ratio is also an indicator of the biochar stability (Spokas 2010, Abdelhafez et al. 2014). For instance, an $\mathrm{O} / \mathrm{C}$ ratio of $0.2-0.6$ confers biochars half-lives of 100-1000 years in the soil, while a ratio $>0.6$ suggests biochars may remain $<100$ years (Spokas 2010). The $\mathrm{O} / \mathrm{C}$ ratio can also account for other biochar properties linked with feedstock, pyrolysis and post-production (Spokas 2010). For instance, as the production temperature increases, the $\mathrm{O} / \mathrm{C}$ ratio decreases (Chen and Chen 2009, Oh et al. 2012, Fernandez et al. 2015), but as biochars oxidize (as may occur with composting), the $\mathrm{O} / \mathrm{C}$ ratio increases until a steady state (Brewer 2012). 
TABLE II. CHEMICAL CHARACTERIZATION OF THE IMMATURE COMPOST, THE UNTREATED AND THE COMPOSTED BIOCHARS FROM THIS STUDY AND PREVIOUS WORKS (UNTREATED BIOCHARS ONLY).

\begin{tabular}{|c|c|c|c|c|c|}
\hline $\begin{array}{l}\text { Variable } \\
\text { (Unit) }\end{array}$ & $\begin{array}{l}\text { Immature compost } \\
\text { Mean } \pm \text { SD }\end{array}$ & $\begin{array}{l}\text { Untreated biochar } \\
\text { Mean } \pm \text { SE }\end{array}$ & $\begin{array}{l}\text { Composted-biochar } \\
\text { Mean } \pm \text { SD }\end{array}$ & $\begin{array}{l}\text { Previous } \\
\text { studies }\end{array}$ & Reference \\
\hline \multirow[t]{2}{*}{ C (\%) } & & & & $40-50$ & 7 \\
\hline & $46.0 \pm 1.1$ & $62.0 \pm 1.4$ & $42.0 \pm 0.6$ & $\begin{array}{l}50-60 \\
60-70 \\
70-80\end{array}$ & $\begin{array}{c}3,6,7,9 \\
1-5,7,8,10,11 \\
3,4,5\end{array}$ \\
\hline N (\%) & $1.02 \pm 0.01$ & $1.82 \pm 0.1$ & $1.77 \pm 0.05$ & $\begin{array}{l}0.5 \\
1-2 \\
2-3 \\
3-4\end{array}$ & $\begin{array}{c}3,10 \\
2-4,7,9 \\
2,3,5-8,11 \\
5\end{array}$ \\
\hline H (\%) & $3.9 \pm 0.5$ & $4.7 \pm 0.1$ & $4.0 \pm 0.17$ & $\begin{array}{l}<2 \\
2-4 \\
4-7\end{array}$ & $\begin{array}{c}2-5 \\
2,3,5-9 \\
2-7,10\end{array}$ \\
\hline $\mathrm{O}(\%)$ & & $22.2 \pm 2.3$ & $30.3 \pm 1.0$ & $\begin{array}{l}\leq 10 \\
11-15 \\
16-30 \\
31-45\end{array}$ & $\begin{array}{c}7 \\
2,4 \\
2,4,6,7,8,9,10 \\
2,7\end{array}$ \\
\hline $\mathrm{C} / \mathrm{N}$ & $45.09 \pm 0.9$ & $34.1 \pm 1.1$ & $23.8 \pm 0.6$ & $\begin{array}{c}18-30 \\
30-44 \\
132\end{array}$ & $\begin{array}{c}5-7,11 \\
2,4,8-10 \\
3\end{array}$ \\
\hline $\mathrm{H} / \mathrm{C}$ & & $0.91 \pm 0.05$ & $1.14 \pm 0.04$ & $\begin{array}{c}\leq 0.30 \\
0.31-0.60 \\
0.61-0.90 \\
0.91-1.20 \\
1.21-1.50\end{array}$ & $\begin{array}{c}2-5 \\
2,5,7,8 \\
2,3,5,6,9 \\
2-4,7,10 \\
2,7\end{array}$ \\
\hline $\mathrm{O} / \mathrm{C}$ & & $0.27 \pm 0.04$ & $0.54 \pm 0.03$ & $\begin{array}{c}\leq 2.0 \\
2.1-4.0 \\
4.1-6.1\end{array}$ & $\begin{array}{c}2,4,7 \\
2,4,6,7,8,9,10 \\
2,7\end{array}$ \\
\hline $\mathrm{pH}$ & $7.4 \pm 0.02$ & $7.6 \pm 0.3$ & $8.51 \pm 0.2$ & $\begin{array}{c}<5 \\
6-8 \\
8-10 \\
>10\end{array}$ & $\begin{array}{c}5 \\
4,7,9 \\
8,13,12 \\
4,6,7,11,13\end{array}$ \\
\hline $\mathrm{EC}(\mathrm{dS} / \mathrm{m})$ & $2.7 \pm 0.16$ & $5.7 \pm 0.2$ & $4.4 \pm 0.1$ & $\begin{array}{c}<1.0 \\
1.1-1.6 \\
6.5-7.2\end{array}$ & $\begin{array}{l}8,12 \\
4,9 \\
4,11\end{array}$ \\
\hline $\mathrm{Fe}(\mathrm{mg} / \mathrm{kg})$ & $48.3 \pm 0.00$ & $3.7 \pm 0.2$ & $131.0 \pm 12.0$ & 215 & 9 \\
\hline $\mathrm{Cu}(\mathrm{mg} / \mathrm{kg})$ & $12.9 \pm 0.12$ & $1.5 \pm 0.3$ & $3.8 \pm 0.7$ & 144 & 9 \\
\hline $\mathrm{Zn}(\mathrm{mg} / \mathrm{kg})$ & $19.0 \pm 0.14$ & $7.1 \pm 0.4$ & $36.0 \pm 1.0$ & 63.7 & 9 \\
\hline $\mathrm{Mn}(\mathrm{mg} / \mathrm{kg})$ & $68.0 \pm 1.41$ & $6.3 \pm 1.3$ & $21.4 \pm 5.1$ & 107 & 9 \\
\hline $\mathrm{P}(\mathrm{mg} / \mathrm{kg})$ & $116.4 \pm 1.4$ & $157.1 \pm 28.2$ & $296 \pm 2.5$ & & \\
\hline $\mathrm{Ca}\left(\mathrm{cmol}_{\mathrm{c}} / \mathrm{kg}\right)$ & $53.8 \pm 22.0$ & $18.6 \pm 1.9$ & $31.1 \pm 0.9$ & $14.2-14.5$ & 4 \\
\hline $\mathrm{Mg}\left(\mathrm{cmol}_{\mathrm{c}} / \mathrm{kg}\right)$ & $7.9 \pm 1.4$ & $4.8 \pm 0.8$ & $10.3 \pm 0.2$ & $3.5-3.6$ & 4 \\
\hline $\mathrm{Na}\left(\mathrm{cmol}_{\mathrm{c}} / \mathrm{kg}\right)$ & $1.2 \pm 0.1$ & $1.0 \pm 0.02$ & $1.4 \pm 0.03$ & & \\
\hline $\mathrm{K}\left(\mathrm{cmol}_{\mathrm{c}} / \mathrm{kg}\right)$ & $7.9 \pm 2.5$ & $34.6 \pm 0.3$ & $31.1 \pm 0.01$ & $8.9-14.1$ & 4 \\
\hline
\end{tabular}

*(1) Titirici et al. 2007; (2) Chen and Chen 2009; (3) Chen et al. 2011; (4) Oh et al. 2012; (5) Pellera et al. 2012; (6) Dai et al. 2013a; (7) Dai et al. 2013b; (8) Abdelhafez et al. 2014; (9) Aon et al. 2015; (10) Fernandez et al. 2015; (11) Prakongkep et al. 2015; (12) Stella Mary et al. 2016; (13) Tran et al. 2016; (14) Wang et al. 2016. SD = standard deviation, SE = standard error 
The $\mathrm{pH}$ of the untreated and composted biochars was 7.6 and 8.5 , respectively $(\mathrm{p}=0.002)$. Some of the $\mathrm{pH}$ values reported in previous studies of untreated biochars were higher than ours $(>8)$ (Table II), except Pellera et al. (2012) whose biochar $\mathrm{pH}$ was 2.42 , probably because authors applied $\mathrm{HCl}$ and deionized water to the biochar, washing possible alkaline substances. Biochar alkalinity is related to the production temperature used, since the higher the temperature and/or residence time, the higher the $\mathrm{pH}$ (Oh et al. 2012, Pellera et al. 2012, Dai et al. 2013).

The EC of the untreated and composted biochars was 5.7 and $4.4 \mathrm{dS} / \mathrm{m}$, respectively $(\mathrm{p}=0.026)$. These values are higher than most of the previous studies with citrus-peel biochars (Table II). Prakongkep et al. (2015) mentioned that fruit wastes might have high contents of minerals (particularly $\mathrm{Ca}, \mathrm{Mg}$ and $\mathrm{K})$. Additionally, EC is related to the production temperatures. Tag et al. (2016), for instance, observed that high-temperature biochars $\left(600{ }^{\circ} \mathrm{C}\right)$ presented higher EC than low-temperature biochars $\left(250^{\circ} \mathrm{C}\right)$ regardless of feedstock. Biochars with alkaline $\mathrm{pH}$ $(>7.5)$ and high EC values $(>4 \mathrm{dS} / \mathrm{m})$ can increase the soil salinity. In acid soils, this could improve the balance among ions and reduce the toxicity of aluminum (Dai et al. 2017). However, there is a risk to increase the soil salinity in neutral or alkaline soils (Saifullah et al. 2018). Thus, $\mathrm{pH}$ and EC values have to be monitored when biochar, composted or not, is applied to soils.

The concentrations of micronutrients, namely $\mathrm{Fe}$ (3.7 mg/kg), Cu (1.5 mg/kg), Zn (7.1 mg/kg) and Mn $(6.3 \mathrm{mg} / \mathrm{kg})$ were small compared to the composted biochar, whose metal concentrations were more than double: Fe (131 mg/kg), Cu (3.8 mg/kg), Zn (36.0 $\mathrm{mg} / \mathrm{kg})$ and $\mathrm{Mn}(21.4 \mathrm{mg} / \mathrm{kg}$ ) (Table II) suggesting that these micronutrients were supplied by the conifer pruning added for composting. Only Fe and $\mathrm{Zn}$ concentrations were significantly different between the untreated and the composted biochar (Fe: $\mathrm{p}=$ $0.002, \mathrm{Cu}: \mathrm{p}=0.24, \mathrm{Zn}: \mathrm{p}=0.002, \mathrm{Mn}: \mathrm{p}=0.12$ ). The biochar produced by Aon et al. (2015) had higher concentrations of micronutrients than our biochars (Table II); citrus peels may contain more $\mathrm{Fe}, \mathrm{Cu}$, $\mathrm{Zn}$ and $\mathrm{Mn}$, than pineapple peels (Prakongkep et al. 2015, Romelle et al. 2016).

The untreated biochar had $157.1 \mathrm{mg} / \mathrm{kg}$ extractable $\mathrm{P}$, which is in line with Xiao et al. (2016) whose straw biochar had a content of $158.5 \mathrm{mg} / \mathrm{kg}$ P. The composted biochar extractable P was $296 \mathrm{mg} / \mathrm{kg}$ which was significantly higher than the untreated one $(p=0.002)$. Depending on the soil and crop requirements, application of biochar along with phosphate fertilizers may be useful. However, biochar may improve the soil $\mathrm{P}$ availability by modifying the soil $\mathrm{pH}$, the $\mathrm{P}$ complexing metals $\left(\mathrm{Ca}^{2+}, \mathrm{Al}^{3+}\right.$ and $\mathrm{Fe}^{3+2+}$ ), the microbial activity or the $\mathrm{P}$ mineralization (DeLuca et al. 2009).

The exchangeable cations of the untreated biochar were $18.6,4.8,1.0$ and $34.6 \mathrm{cmol}_{\mathrm{C}} / \mathrm{kg}$, for $\mathrm{Ca}, \mathrm{Mg}$, $\mathrm{Na}$ and $\mathrm{K}$, respectively; while for the composted biochar values were $31.1,10.3,1.4,31.1 \mathrm{cmol}_{\mathrm{c}} / \mathrm{kg}$, for the same ions $(\mathrm{Ca}: \mathrm{p}=0.005, \mathrm{Mg}: \mathrm{p}=0.005, \mathrm{Na}$ : $\mathrm{p}=0.004, \mathrm{~K}: \mathrm{p}=0.005$; Table II). Composting the biochar increased significantly all the exchangeable cations except $\mathrm{K}$, which means that this method could rise nutrient content of the amendment but also its alkalinity (Na increase). Compared to other studies, our untreated biochar results are in line with $\mathrm{Oh}$ et al. (2012) except for K, which in our case was more than double. This could be attributed to the mixture of feedstock we used compared to their orange peels biochar. Namely, pineapple peels can have higher K concentrations than orange peels making them more beneficial to soil (Prakongkep et al. 2015).

The FT-IR spectra of our biochars have few $\mathrm{OH}$ groups $\left(\sim 3600 \mathrm{~cm}^{-1}\right)$ in their composition. We did not observe the presence of the band $\sim 1700$ which corresponds to the $\mathrm{COOH}$ region. The $\sim 1600 \mathrm{~cm}^{-1}$ band, which corresponds to the aromatic $\mathrm{C}=\mathrm{C}$ and to the COO-carboxylates, presents a greater intensity in the composted biochar. Fernandez et al. (2015) interpret the increase in these signals as an increase in the aromatic structures within the biochar, promoting favorable conditions for the adsorption of compounds such as pyrene (Wang et al. 2016). However, it should be noted that in the case of the composted biochar this region could be attributed to the increase of $\mathrm{COO}$-groups by the composing process (the composted biochar has more exchangeable COO- sites than the untreated biochar). This means the composted biochar has greater cation exchange capacity than the untreated one (as shown by the exchangeable cations sum) because the carboxylates and hydroxyl groups are responsible for this property (Stella Mary et al. 2016). However, due to the $\mathrm{pH}$ (7.6 and 8.8) these groups are deprotonated ( $\left.\mathrm{pK}_{\mathrm{COOH}} \sim 3.5-4\right)$. This explains the absence or few $\mathrm{OH}$ groups $\left(\sim 3600 \mathrm{~cm}^{-1}\right)$, which could form part of the $\mathrm{COOH}$ region.

The energy absorption bands of the $\mathrm{CH}$ bonds of aliphatic systems $\left(3000-2800 \mathrm{~cm}^{-1}\right)$ show higher values in the composted biochar than in the untreated one; by integrating this region we found that the area is larger in the composted than in the untreated biochar. This region of the spectrum has been used 
to predict whether the material has potentially mineralizable compounds or not (Capriel et al. 1995).

The band indicating $\mathrm{C}-\mathrm{O}$ bonds within aromatic systems $\left(\mathrm{C}-\mathrm{O} 1370 \mathrm{~cm}^{-1}\right)$ is slightly higher $(16 \%)$ in the composted than in the untreated biochar. This region can also be attributed to nitro-compounds $\left(\mathrm{NO}_{2} 1374 \mathrm{~cm}^{-1}\right)$ (Stella Mary et al. 2016). This could be relevant because its relation with the number of substitutions present in such aromatic systems.

The energy absorption bands of the oxygen base groups within aliphatic chains (C-O 1020 and $1000 \mathrm{~cm}^{-1}$ ) are $40-50 \%$ more intense in the composted biochar. Dai et al. (2013) point out that the 1000 $\mathrm{cm}^{-1}$ band is due to C-O of alcohols derived from intact cellulose and hemicellulose. These functional groups may form part of the cellulose, partially mineralized or not. The increase of these oxygen-based functional groups (COO-, $\mathrm{C}-\mathrm{O}$ aromatic and $\mathrm{C}-\mathrm{O}$ aliphatic) is in line with the values of the $\mathrm{H} / \mathrm{O}$ ratio, confirming the increase of oxygen base groups due to the composting process.

Based on the signal of the energy absorption bands corresponding to the $\mathrm{CH}$ bonds of aromatic systems $\left(860,800,750 \mathrm{~cm}^{-1}\right)$ it can be inferred that there is the same proportion of di- and mono-substituted systems in the untreated biochar, because the intensity of these bands has the same value. In the composted biochar a greater abundance of di-substituted systems is observed. This difference could be attributed to the composting process or the humification process (mineralization and microbiological transformation) of lignin. The differences in the proportion of aliphatic and aromatic compounds influence the sorption behavior of the polar and non-polar hydrophobic organic compounds. Chen and Chen (2009), for instance, found that by increasing the degree of biochar aromaticity (e.g., those produced at high temperatures) the affinity for non-polar hydrophobic organic compounds, such as the naphthalene, increases too, while the presence of aliphatic compounds increases the affinity of the polar hydrophobic organic compounds (1-naphtol). The above increases the biochar affinity to non-polar hydrophobic organic compounds, and composting it, promotes the adsorption of polar hydrophobic organic compounds.

Aliphatic oxygen base groups, $\mathrm{O} / \mathrm{C}$ ratio 0.54 and high hydrophobicity confirm that the composting process enriches the material with short residence time (labile) carbon such as cellulose-like substances. The untreated biochar offers a more promising option for the long-term stabilization of soil carbon.

In presence of the untreated biochar, germination was significantly low $(66.7 \pm 13.3 \% ; \mathrm{p}=0.0016)$ compared to the control $(90.0 \pm 0.0 \%)$ and to the composted biochar $(90.0 \pm 5.8 \%)$. According to prior studies, low-temperature biochars may suppress germination due to the existence of toxic compounds (Oh et al. 2012, Liang et al. 2016). Although some biochar toxicants can be quickly degraded in a couple of days, highly resistant PAHs or other substances may further persist, thus treatments to eliminate them should be carried out (Borchard et al. 2014).

The untreated biochar has higher concentrations of PCDD/PCDF and PAHs than the composted biochar (Table III). This indicates that composting can be an effective way to reduce the toxicity of biochars (Borchard et al. 2014). It is worth mentioning that both biochars have PCDD/PCDF and PAHs concentrations below the maximum allowed thresholds according to IBI (2015) and EBC (2017) guidelines.

Compared to other biochars, Hale et al. (2012) reported total dioxin concentrations from 0.005 to $1.2 \mathrm{ng} / \mathrm{kg}$ for ca. 50 biochars produced via slow pyrolysis $\left(250-900{ }^{\circ} \mathrm{C}\right)$, using different feedstock such as manure, food waste, straw or wood. Authors pointed out that the higher levels of dioxins could be attributed to a high $\mathrm{NaCl}$ content in the biomass. PAHs concentrations of biochar reported by Madej et al. (2016) were $<1.5 \mathrm{mg} / \mathrm{kg}$ in biochars from wood and straw biomass pyrolyzed at 500,600 and $700{ }^{\circ} \mathrm{C}$ for $4 \mathrm{~h}$, detecting the lowest PAHs concentrations at $600{ }^{\circ} \mathrm{C}$. Gondek et al. (2017) found the highest total content of PAHs in rape straw biochar $(3.564 \mathrm{mg} / \mathrm{kg})$, and the lowest in sawdust biochar $(0.105 \mathrm{mg} / \mathrm{kg})$, attributing the PAHs concentrations to the pyrolysis and to the feedstocks characteristics.

Hardwood biochars had non-detectable concentrations of naphthalene and furan six months after composting according to Borchard et al. (2014). In our case, toxicants reduction was more evident for $1,2,3,4,6,7,8-\mathrm{HpCDD}$, OCDD, all the PCDF, fluorene, naphthalene and phenanthrene (Table III).

It is worth mentioning that the composted biochar was applied to a highly saline-sodic soil and monitored during a 2-year field test (Chávez-García and Siebe 2019). Results showed this amendment was the most recommendable to be used (compared with another biochar and one compost), due to its positive effects on the survival of a saltgrass (Distichlis spicata), soil organic matter increase and minimal GHG emissions.

\section{CONCLUSIONS}

Composting of biochars has the potential to improve the fertility and carbon sequestration properties 
TABLE III. CONCENTRATIONS OF POLYCHLORINATED DIBENZO-P-DIOXINS, POLYCHLORINATED DIBENZOFURANS AND POLYCYCLIC AROMATIC HYDROCARBONS (PAHs) OF THE UNTREATED AND COMPOSTED BIOCHARS.

\begin{tabular}{lcc}
\hline Toxicant & Untreated biochar & Composted-biochar \\
\hline Polychlorinated dibenzo-p-dioxins & {$[\mathrm{ng} / \mathrm{kg} \mathrm{dw}]$} & {$[\mathrm{ng} / \mathrm{kg} \mathrm{dw}]$} \\
2,3,7,8-Tetrachlorodibenzodioxin & $<1$ & $<1$ \\
1,2,3,7,8-Pentachlorodibenzo-P-dioxin & $<1$ & $<1$ \\
1,2,3,4,7,8-Hexachlorodibenzo-P-dioxin & $<1$ & $<1$ \\
1,2,3,6,7,8-Hexachlorodibenzo-P-dioxin & $<1$ & $<1$ \\
1,2,3,7,8,9-Hexachlorodibenzo-P-dioxin & $<1$ & $<1$ \\
1,2,3,4,6,7,8-Heptachlorodibenzo-P-dioxin & 54 & $<5$ \\
Octachlorodibenzodioxin & 494 & $<15$ \\
Polychlorinated dibenzofurans & {$[\mathrm{ng} / \mathrm{kg} \mathrm{dw}]$} & {$[\mathrm{ng} / \mathrm{kg} \mathrm{dw}]$} \\
2,3,7,8-Tetrachlorodibenzofuran & 3 & $<1$ \\
1,2,3,7,8-Pentachlorodibenzofuran & 1 & $<1$ \\
2,3,4,7,8- Pentachlorodibenzofuran & 2 & $<1$ \\
1,2,3,4,7,8-Hexachlorodibenzofuran & 2 & $<1$ \\
1,2,3,6,7,8- Hexachlorodibenzofuran & 2 & $<1$ \\
1,2,3,7,8,9- Hexachlorodibenzofuran & 1 & $<1$ \\
2,3,4,6,7,8- Hexachlorodibenzofuran & 2 & $<3$ \\
1,2,3,4,6,7,8-Heptachlorodibenzofuran & 13 & $<3$ \\
1,2,3,4,7,8,9- Heptachlorodibenzofuran & 3 & $<10$ \\
Octachlorodibenzofuran & 17 & {$[\mathrm{ng} / \mathrm{kg} \mathrm{dw}]$} \\
Toxicity equivalents & {$[\mathrm{ng} / \mathrm{kg} \mathrm{dw}]$} & 3.0 \\
NATO/CCMS-TE (I-TEQ) & 5.1 & 3.5 \\
WHO-TEQ 1998 & 5.1 & 3.2 \\
WHO-TEQ 2005 & 4.8 & {$[\mathrm{mg} / \mathrm{kg} \mathrm{dw}]$} \\
Polycyclic aromatic hydrocarbons & {$[\mathrm{mg} / \mathrm{kg} \mathrm{dw}]$} & $<0.1$ \\
Acenaphthene & $<0.1$ & $<0.1$ \\
Acenaphthylene & 0.1 & 0.1 \\
Anthracene & 0.3 & 0.1 \\
Benz(a)anthracene & 0.2 & $<0.1$ \\
Benzo(a)pyrene & 0.1 & $<0.1$ \\
Benzo(b)fluoranthene & $<0.1$ & $<0.1$ \\
Benzo(g,h,i)perylene & $<0.1$ & $<0.1$ \\
Benzo(k)fluoranthene & $<0.1$ & 0.2 \\
Chrysene & 0.2 & $<0.1$ \\
Dibenz(a,h)anthracene & $<0.1$ & 0.3 \\
Fluoranthene & 0.3 & 0.1 \\
Fluorene & 0.4 & 0.1 \\
Indeno(1,2,3-cd)pyrene & $<0.1$ & 0.8 \\
Naphthalene & 1.4 & 0.5 \\
Phenanthrene & 0.9 & 0.3 \\
Pyrene & 0.4 & 2.5 \\
EPAHs (EPA) & 4.5 & \\
\hline & & \\
\hline
\end{tabular}

$\mathrm{dw}=$ dry weight, $\mathrm{EPA}=$ United States Environmental Protection Agency, NATO/CCMS-TE $(\mathrm{I}-\mathrm{TEQ})=$ North Atlantic Treaty Organisation/Comitee on the Challenges of the Modern Society/Toxic Equivalent (International Toxic Equivalent), WHO-TEQ =World Health Organization-Toxic equivalent

of these amendments, while reducing the volume of organic waste. In this study, properties such as the $\mathrm{TPV}$ and the nutrient contents (Fe, $\mathrm{P}, \mathrm{Ca}$ and $\mathrm{Mg}$ ) were higher in the composted than in the untreated biochar. Additionally, both biochars had higher values of WHC and TPV compared to other biochars from similar feedstock, a favorable feature in dry or polluted soils. Possible toxicity of the untreated biochar can be avoided by composting with non-charred organic residues, while contributing to the increase 
in nutrient concentration of the amendment. Therefore, composted biochar produced out of orange and pineapple peels can be a promising soil amendment due the combination of a stable $\mathrm{C}$-rich material, labile organic matter rich in nutrients and low toxicants according to existing biochar regulations. Field studies under different soil conditions are recommended for a deeper understanding of composted biochar as soil amendment and plant fertilizer.

\section{ACKNOWLEDGMENT}

We thank the Posgrado en Ciencias Biológicas (UNAM) and the Consejo Nacional de Ciencia y Tecnología for the scholarship granted to Elizabeth Chávez during her doctoral degree studies. The study was funded by the Programa de Apoyo a Proyectos para Innovar y Mejorar la Educación (PAPIMEUNAM), project PE 102217. Argemiro Palencia, Arturo Fuerte and Alicia Lasso from the Instituto de Ingeniería UNAM helped in the biochar production. Kumiko Shimada, Lucy Mora, René Alcalá and Iris Suárez from the Instituto de Geología UNAM helped with the biochar characterization and the facilities for the greenhouse experiment. We acknowledge the staff of UNAM's Academic Writing Program for their support with the drafting of this manuscript.

\section{REFERENCES}

Abdelhafez A.A., Li J. and Abbas M.H.H. (2014). Feasibility of biochar manufactured from organic wastes on the stabilization of heavy metals in a metal smelter contaminated soil. Chemosphere 117, 66-71.

DOI: 10.1016/j.chemosphere.2014.05.086

Aon M., Khalid M., Zahir Z.A. and Ahmad R. (2015). Low temperature produced citrus peel and green waste biochar improved maize growth and nutrient uptake, and chemical properties of calcareous soil. Pakistan J. Agric. Sci. 52, 627-636.

Bass A.M., Bird M.I., Kay G. and Muirhead B. (2016). Soil properties, greenhouse gas emissions and crop yield under compost, biochar and co-composted biochar in two tropical agronomic systems. Sci. Total Environ. 550: 459-470. DOI: 10.1016/j.scitotenv.2016.01.143

Borchard N., Spokas K., Prost K. and Siemens J. (2014). Greenhouse gas production in mixtures of soil with composted and noncomposted biochars is governed by char-associated organic compounds. J. Environ. Qual. 43 (3), 971-979.

DOI: $10.2134 /$ jeq2013.07.0290
Bower C.A., Reitemeier R.F. and Fireman R. (1952). Exchangeable cation analysis of saline and alkali soils. Soil Sci. 73 (4), 251-262.

DOI: 10.1097/00010694-195204000-00001

Brewer C.E. (2012). Biochar characterization and engineering. Ph.D. Thesis. Iowa State University. Iowa, USA, $182 \mathrm{pp}$.

Capriel P., Beck T., Borchert H., Gronholz J. and Zachmann G. (1995). Hydrophobicity of the organic matter in arable soils. Soil Biol. Biochem. 27 (11), 1453-1458. DOI: $10.1016 / 0038-0717(95) 00068-P$

Celi L., Schnitzer M. and Nègre M. (1997). Analysis of carboxyl groups in soil humic acids by a wet chemical method, fourier-transform infrared spectrophotometry, and solution-state carbon-13 nuclear magnetic resonance. A comparative study. Soil Sci. 162 (3), 189-197. DOI: 10.1097/00010694-199703000-00004

CEFP (2002). La problemática actual de la producción de piña en México. Centro de Estudios de las Finanzas Públicas. Cámara de Diputados. Palacio Legislativo de San Lázaro, Mexico City, Mexico, 43 pp.

Cha J.S., Park S.H., Jung S.-C., Ryu C., Jeon J.-K., Shin M.-C. and Park Y.-K. (2016). Production and utilization of biochar: A review. J. Ind. Eng. Chem. 40, 1-15. DOI: $10.1016 /$ j.jiec.2016.06.002

Chávez-García E. and Siebe C. (2019). Rehabilitation of a highly saline-sodic soil using a rubble barrier and organic amendments. Soil Till. Res. 189, 176-188. DOI: $10.1016 /$ j.still.2019.01.003

Chen B. and Chen Z. (2009). Sorption of naphthalene and 1-naphthol by biochars of orange peels with different pyrolytic temperatures. Chemosphere 76 (1), 127-133. DOI: 10.1016/j.chemosphere.2009.02.004

Chen B., Chen Z. and Lv S. (2011). A novel magnetic biochar efficiently sorbs organic pollutants and phosphate. Bioresour. Technol. 102 (2), 716-723. DOI: 10.1016/j.biortech.2010.08.067

Chun Y., Sheng G., Chiou G.T. and Xing B. (2004). Compositions and sorptive properties of crop residuederived chars. Environ. Sci. Technol. 38 (17), 46494655. DOI: $10.1021 / \mathrm{es} 035034 \mathrm{w}$

Dai Z., Meng J., Muhammad N., Liu X., Wang H., He Y., Brookes P.C. and Xu J. (2013). The potential feasibility for soil improvement, based on the properties of biochars pyrolyzed from different feedstocks. J. Soils Sediments 13 (6), 989-1000. DOI: $10.1007 / \mathrm{s} 11368-013-0698-\mathrm{y}$

Dai Z., Li R., Muhammad N., Brookes P.C., Wang H., Liu X. and Xu J. (2014). Principle component and hierarchical cluster analysis of soil properties following biochar incorporation. Soil Sci. Soc. Am. J. 78(1), 205-213.

DOI: 10.2136/sssaj2013.05.0199 
Dai Z., Zhang X., Tang C., Muhammad N., Wu J., Brookes P.C. and Xu J. (2017). Potential role of biochars in decreasing soil acidification - a critical review. Sci. Total Environ. 581-582, 601-611.

DOI: $10.1016 / j$. scitotenv.2016.12.169

DeLuca T.H., MacKenzie M.D. and Gundale M.J. (2009). Biochar effects on soil nutrient transformation. In: Biochar for Environmental Management: Science and Technology (J. Lehmann and S. Joseph, Eds.). Earthscan, London, UK, pp. 251-270.

Downie A., Crosky A. and Munroe P. (2009). Physical properties of biochar, In: Biochar for Environmental Management: Science and Technology (J. Lehmann and S. Joseph, Eds.). Earthscan, London, UK, pp. 13-32.

Epstein E. (2011). Industrial composting. Environmental Engineering and Facilities Management. CRC Press, Taylor and Francis Group, Boca Raton, FL, USA, $314 \mathrm{pp}$.

EBC (2017). Guidelines for a sustainable production of biochar. European Biochar Certificate. European Biochar Foundation, Arbaz, Switzerland, 24 pp.

Fernandez M.E., Ledesma B., Román S., Bonelli P.R. and Cukierman A.L. (2015). Development and characterization of activated hydrochars from orange peels as potential adsorbents for emerging organic contaminants. Bioresour. Technol. 183, 221-228.

DOI: 10.1016/j.biortech.2015.02.035

FAO (2014). Statistical yearbook. Latin America and the Caribbean. Food and Agricultural Organization of the United Nations. Statistics Division, Rome, Italy,180 pp.

FAO (2015). Citrus fruit statistics 2015. Food and Agricultural Organization of the United Nations, Rome, Italy, $53 \mathrm{pp}$.

Gómez M. and Schwentesius R. (1997). La agroindustria de naranja en México, Secretaría de agricultura, ganadería y desarrollo rural. Universidad Autónoma Chapingo. State of Mexico, Mexico, 181 pp.

Gondek K., Mierzwa-Hersztek M., Baran A., Szostek M., Pieniążek R., Pieniążek M., Stanek-Tarkowska J. and Noga T. (2017). The effect of low-temperature conversion of plant materials on the chemical composition and ecotoxicity of biochars. Waste Biomass Valori. 8 (3), 599-609.

DOI: $10.1007 / \mathrm{s} 12649-016-9621-2$

Hale S.E., Lehmann J., Rutherford D., Zimmerman A.R., Bachmann R.T., Shitumbanuma V., O'Toole A., Sundqvist K.L., Arp H.P.H. and Cornelissen G. (2012). Quantifying the total and bioavailable polycyclic aromatic hydrocarbons and dioxins in biochars. Environ. Sci. Technol. 46 (5), 2830-2838.

DOI: $10.1021 / \mathrm{es} 203984 \mathrm{k}$
IBI (2015). Standardized product definition and product testing guidelines for biochar that is used in soil. v. 2.1. International Biochar Initiative [online]. https:// biochar-international.org/characterizationstandard/ 23/10/2015.

Ketnawa S., Chaiwut P. and Rawdkuen S. (2012). Pineapple wastes: A potential source for bromelain extraction. Food Bioprod. Process. 90 (3), 385-391.

DOI: $10.1016 /$ j.fbp.2011.12.006

Kinney T.J., Masiello C.A., Dugan B., Hockaday W.C., Dean M.R., Zygourakis K. and Barnes R.T. (2012). Hydrologic properties of biochars produced at different temperatures. Biomass Bioenerg. 41, 34-43.

DOI: 10.1016/j.biombioe.2012.01.033

Lam S.S., Liew R.K., Lim X.Y., Ani F.N. and Jusoh A. (2016). Fruit waste as feedstock for recovery by pyrolysis technique. Int. Biodeterior. Biodegrad. 113, 325-333.

DOI: 10.1016/j.ibiod.2016.02.021

Lehmann J. (2007). Bio-energy in the black. Front. Ecol. Environ. 5 (7), 381-387. DOI: 10.1890/060133

Liang C., Gascó G., Fu S., Méndez A. and Paz-Ferreiro J. (2016). Biochar from pruning residues as a soil amendment: Effects of pyrolysis temperature and particle size. Soil Tillage Res. 164, 3-10.

DOI: $10.1016 /$ j.still.2015.10.002

Lindsay W.L. and Norvell W.A. (1978). Development of a DTPA soil test for zinc, iron, manganese and copper. Soil Sci. Soc. Am. J. 42 (3), 421-428. DOI: 10.2136/sssaj1978.03615995004200030009x

Liu Z., Dugan B., Masiello C.A. and Gonnermann H.M. (2017). Biochar particle size, shape, and porosity act together to influence soil water properties. PLoS One 12 (6), e0179079. DOI: 10.1371/journal.pone.0179079

Madej J., Hilber I., Bucheli T.D. and Oleszczuk P. (2016). Biochars with low polycyclic aromatic hydrocarbon concentrations achievable by pyrolysis under high carrier gas flows irrespective of oxygen content or feedstock. J. Anal. Appl. Pyrolysis 122, 365-369.

DOI: 10.1016/j.jaap.2016.09.005

Michler L. (2013). Assessment of compost produced from organic urban residues by the processing plant of Mexico City. B.Sc. Thesis. University of Hohenheim and Universidad Nacional Autónoma de México. Stuttgart, Germany, 55 pp.

Nanda S., Isen J., Dalai A.K. and Kozinski J.A. (2016). Gasification of fruit wastes and agro-food residues in supercritical water. Energy Convers. Manag. 110, 296306. DOI: 10.1016/j.enconman.2015.11.060

Oh T.K., Shinogi Y., Chikushi J., Lee Y.H. and Choi B. (2012). Effect of aqueous extract of biochar on germination and seedling growth of lettuce (Lactuca sativa L.). J. Fac. Agr. Kyushu U. 57 (1), 55-60. 
Pellera F.M., Giannis A., Kalderis D., Anastasiadou K., Stegmann R., Wang J.Y. and Gidarakos E. (2012). Adsorption of $\mathrm{Cu}(\mathrm{II})$ ions from aqueous solutions on biochars prepared from agricultural by-products. J. Environ. Manage. 96 (1), 35-42.

DOI: $10.1016 /$ j.jenvman.2011.10.010

Petiot C. and de Guardia A. (2004). Composting in a laboratory reactor: A review. Compost Sci. Util. 12 (1), 69-79.

DOI: $10.1080 / 1065657 X .2004 .10702160$

Pohlert T. (2014). The pairwise multiple comparison of mean ranks package (PMCMR). R package [online]. https://rdrr.io/cran/PMCMR/. 13/11/2016.

Prakongkep N., Gilkes R.J. and Wiriyakitnateekul W. (2015). Forms and solubility of plant nutrient elements in tropical plant waste biochars. J. Plant Nutr. Soil Sci. 178 (5), 732-740.

DOI: $10.1002 / j p l n .201500001$

RDCT (2018). R: A language and environment for statistical computing. R Foundation for Statistical Computing, Vienna, Austria [online]. https://www.r-project. org/ 18/04/2014.

Rohrbach G.K., Leal F. and Coppens D'Eeckenbrugge G. (2003). History, distribution and world production, In: The Pineapple: Botany, Production, and Uses (D.P. Bartholomew, R.E. Paull and K.G. Rohrbach, Eds.), CABI Publishing. Honolulu, USA, pp. 1-12.

Romelle F.D., Rani A. and Manohar R.S. (2016). Chemical composition of some selected fruit peels. Eur. J. Food Sci. Technol. 4 (4), 12-21.

Saifullah, Dahlawi S., Naeem A., Rengel Z. and Naidu R. (2018). Biochar application for the remediation of salt-affected soils: challenges and opportunities. Sci. Total Environ. 625, 320-335.

DOI: $10.1016 /$ j.scitotenv.2017.12.257

Santos L.B., Striebeck M.V., Crespi M.S., Ribeiro C.A. and De Julio M. (2015). Characterization of biochar of pine pellet. J. Therm. Anal. Calorim. 122 (1), 21-32. DOI: $10.1007 / \mathrm{s} 10973-015-4740-8$

Schimmelpfennig S. and Glaser B. (2012). One step forward toward characterization: some important material properties to distinguish biochars. J. Environ. Qual. 41 (4), 1001-1013. DOI: $10.2134 /$ jeq2011.0146

SEDEMA (2017). Inventario de residuos sólidos CDMX 2017. Secretaría del Medio Ambiente del Gobierno de la Ciudad de México, Mexico City, Mexico, 163 pp.

Spokas K.A. (2010). Review of the stability of biochar in soils: predictability of O:C molar ratios. Carbon Manag. 1 (2), 289-303.

DOI: $10.4155 / \mathrm{cmt} .10 .32$

Stella Mary G., Sugumaran P., Niveditha S., Ramalakshmi B., Ravichandran P. and Seshadri S. (2016). Production, characterization and evaluation of biochar from pod (Pisum sativum), leaf(Brassica oleracea) and peel (Citrus sinensis) wastes. Int. J. Recycl. Org. Waste Agric. 5 (1), 43-53. DOI: 10.1007/s40093-016-0116-8

Sun X., Shan R., Li X., Pan J., Liu X., Deng R. and Song J. (2017). Characterization of 60 types of Chinese biomass waste and resultant biochars in terms of their candidacy for soil application. GCB Bioenergy 9 (9), 1423-1435. DOI: $10.1111 /$ gcbb. 12435

Tag A.T., Duman G., Ucar S. and Yanik J. (2016). Effects of feedstock type and pyrolysis temperature on potential applications of biochar. J. Anal. Appl. Pyrolysis 120, 200-206. DOI: 10.1016/j.jaap.2016.05.006

TTEI (2013). Experiencias internacionales en el composteo de residuos sólidos orgánicos. Programa para el Desarrollo Bajo en Emisiones de México (MLED). Tetra Tech ES Inc. Mexico City, Mexico, 83 pp.

Titirici M.M., Thomas A., Yu S.-H., Müller J.-O. and Antonietti M. (2007). A direct synthesis of mesoporous carbons with bicontinuous pore morphology from crude plant material by hydrothermal carbonization. Chem. Mater. 19 (17), 4205-4212.

DOI: $10.1021 / \mathrm{CM} 0707408$

Tran H.N., You S.-J. and Chao H.-P. (2016). Effect of pyrolysis temperatures and times on the adsorption of cadmium onto orange peel derived biochar. Waste Manag. Res. 34 (2), 129-138.

DOI: $10.1177 / 0734242 X 15615698$

Tripathi M., Sahu J.N. and Ganesan P. (2016). Effect of process parameters on production of biochar from biomass waste through pyrolysis: A review. Renew. Sustain. Energy Rev. 55, 467-481. DOI: 10.1016/j.rser.2015.10.122

Tsai W.T., Liu S.C., Chen H.R., Chang Y.M. and Tsai Y.L. (2012). Textural and chemical properties of swine-manure-derived biochar pertinent to its potential use as a soil amendment. Chemosphere 89 (2), 198-203. DOI: 10.1016/j.chemosphere.2012.05.085

van Reeuwijk L.P. (1992). Procedures for soil analysis. International Soil Reference and Information Centre. Food and Agriculture Organization of the United Nations, Wageningen, The Netherlands, 119 pp.

Wang C., Gu L., Liu X., Zhang X., Cao L. and Hu X. (2016). Sorption behavior of Cr(VI) on pineapple-peelderived biochar and the influence of coexisting pyrene. Int. Biodeterior. Biodegrad. 111, 78-84.

DOI: 10.1016/j.ibiod.2016.04.029

Wiedemeier D.B., Abiven S., Hockaday W.C., Keiluweit M., Kleber M., Masiello C.A., McBeath A.V., Nico P.S., Pyle L.A., Schneider M.P.W., Smernik R.J., Wiesenberg G.L.B. and Schmidt M.W.I. (2015). Aromaticity and degree of aromatic condensation of char. Org. Geochem. 78, 135-143.

DOI: 10.1016/j.orggeochem.2014.10.002 
Wiedner K., Fischer D., Walther S., Criscuoli I., Favilli F., Nelle O. and Glaser B. (2015). Acceleration of biochar surface oxidation during composting? J. Agric. Food Chem. 63 (15), 3830-3837.

DOI: $10.1021 /$ acs.jafc.5b00846

Xiao Q., Zhu L.X., Zhang H.P., Li X.Y., Shen Y.F. and Li S.Q. (2016). Soil amendment with biochar increases maize yields in a semi-arid region by improving soil quality and root growth. Crop Pasture Sci. 67 (5), 495-507. DOI: $10.1071 / \mathrm{CP} 15351$
Zema D.A., Calabro P., Folino A., Tamburino V., Zappia G. and Zimbone S.M. (2018). Valorisation of citrus processing waste: A review. Waste Manag. 80, 252273. DOI: 10.1016/j.wasman.2018.09.024 